• 研究报告・

\title{
丹江口水库鱼类群落特征及其历史变化
}

\author{
白敬沛 ${ }^{1} \quad$ 黄 $^{\text {耿 }^{1 *}}$ 蒋长军 $^{1}$ 章伟成 $^{1}$ 王齐东 $^{2} \quad$ 姚伦广 $^{1^{*}}$ \\ 1 (南阳师范学院南水北调中线水源区水安全河南省协同创新中心, 河南省南水北调中线水源区生态安全重点实验室, \\ 河南省南水北调水源区水安全院士工作站, 河南南阳 473061) \\ 2 (中国科学院水生生物研究所淡水生态与生物技术国家重点实验室, 武汉 430072)
}

摘要: 为了解丹江口水库鱼类群落现状及历史变化, 作者于2018-2019年采用多网目复合刺网采样和渔民渔获物 调查的方式对丹江口水库进行了鱼类群落调查。本次调查共采集鱼类33种, 隶属5目11科29属, 以鲤科鱼类为主, 占总数的 $63.6 \%$ 。基于多网目复合刺网采样的鱼类群落多样性指数和单位努力捕捞量(catch per unit effort, CPUE, $\mathrm{g} \cdot \mathrm{day}^{-1} \cdot \mathrm{m}^{-2}$ ) 在各采样点间具有一定的差异。目前丹江口水库以定居性、喜静缓流、杂食性和肉食性鱼类为主。与 20 世纪50年代和 80 年代的历史资料相比, 丹江口水库鱼类物种丰富度先升高后下降; 而生态类型则呈现杂食性鱼 类、喜流水性鱼类和洄游性鱼类比例持续下降的趋势。2018-2019年丹江口水库鱼类组成与20世纪80年代的相似 性指数为 0.35 (中等不相似), 与 20 世纪 50 年代的相似性指数为 0.29 (中等不相似)。调查结果表明半个世纪以来丹江 口水库鱼类群落结构发生了较大变化, 目前趋于小型化和简单化。这些变化可能是由大坝建设、渔业放养、不合 理捕捞、外来鱼类引入等人类活动所致。

关键词: 鱼类群落; 历史变化; 生态类型; 人类活动; 丹江口水库

\section{Characteristics and historical changes of the fish assemblage in the Danjiangkou Reservoir}

Jingpei Bai ${ }^{1}$, Geng Huang ${ }^{1 *}$, Changjun Jiang ${ }^{1}$, Weicheng Zhang ${ }^{1}$, Qidong Wang ${ }^{2}$, Lunguang Yao ${ }^{1^{*}}$

1 Collaborative Innovation Center of Water Security for Water Source Region of Mid-line of South-to-North Diversion Project of Henan Province, Henan Provincal Key Laboratory of Ecological Security for Water Source Region of Mid-line of South-to-North Diversion Project, Henan Provincal Academician Workstation of Water Security, Nanyang Normal University, Nanyang, Henan 473061

2 State Key Laboratory of Freshwater Ecology and Biotechnology, Institute of Hydrobiology, Chinese Academy of Sciences, Wuhan 430072

Abstract: To quantify the fish assemblage and its historical change, we conducted surveys in the Danjiangkou Reservoir in 2018 and 2019 based on multi-mesh gillnet samplings and catch by fisheries. A total of 33 fish species were collected, belonging to 5 orders, 11 families, and 29 genera, among which Cyprinidae were dominant, accounting for $63.6 \%$ of the total species captured. Spatial variation of diversity indices and catch per unit effort (CPUE, g. $\mathrm{day}^{-1} \cdot \mathrm{m}^{-2}$ ) based on gillnet samplings were calculated among sampling sites. Currently, the Danjiangkou Reservoir is dominated by sedentary, lentic, omnivorous and carnivorous fishes. Compared with historical data from the 1950s and 1980s, the number of total fish species in the reservoir increased and then subsequently decreased. Whereas the proportion of omnivorous species, lotic species, and migratory species showed a continuous decline. The similarity indices of species composition between the present and the 1950s and 1980s were 0.35 and 0.29 , respectively (both medium dissimilarity). These results indicate that the current fish assemblage in the Danjiangkou Reservoir has undergone significant changes in the last half-century trending toward smaller species and simpler assemblages, which may be attributed to human activities such as dam construction, fish stocking, overfishing, and the introduction of non-native fish species.

Key words: fish assemblage; historical change; ecological type; human activity; the Danjiangkou Reservoir

收稿日期: 2020-01-08; 接受日期: 2020-05-19

基金项目: 河南省重点研发与推广专项(192102310305)和南阳师范学院博士专项(2019ZX025)

* 共同通讯作者 Co-authors for correspondence. E-mail: wangyoukl@126.com; lunguangyao@163.com 
南水北调工程是优化我国水资源配置的重大 战略工程, 有效地缓解了我国水资源分布不均的局 面 (张全发等, 2007)。丹江口水库 $\left(110^{\circ} 34^{\prime} 47^{\prime \prime}-\right.$ $110^{\circ} 47^{\prime} 53^{\prime \prime} \mathrm{E}, 32^{\circ} 14^{\prime} 10^{\prime \prime}-32^{\circ} 58^{\prime} 10^{\prime \prime} \mathrm{N}$ ) 是南水北调中 线工程的唯一水源地, 位于汉江中上游, 水域横跨 鄂、豫两省, 也是国家一级水源保护区。丹江口水 利枢纽于1958年开始修建, 1974年初竣工。为实施 南水北调中线工程, 2005年9月, 丹江口大坝加高工 程开工, 2012年丹江口大坝加高后继续蓄水, 坝顶 高程从162 m加高至176.6 m, 正常蓄水位由初期工 程的 $157 \mathrm{~m}$ 提高到 $170 \mathrm{~m}$, 总库容达到 339 亿 $\mathrm{m}^{3}$, 水 面面积达到1,050 km² (付建军等, 2015)。目前, 丹江 口水库生态系统也面临一些问题。由于大坝的修建, 以及实施引水工程后水量的再分配, 使调出区水 文情势发生变化, 不可避免地对丹江口水库生态 系统造成影响; 同时, 其他人类干扰如渔业利用、 过度捕捞等也在不同程度上影响着丹江口水库生 态系统。

鱼类是水域生态系统中重要的水生生物资源 之一, 属于水域生态系统食物网的主要消费者，与 水库环境相互作用、相互影响(Lyons et al, 2000)。 鱼类群落结构往往是衡量和决定水库生态状况的 重要指标, 目前已广泛地运用到世界各种水体的水 域生态系统评价中(Drake \& Valley, 2005; Vehanen et al, 2010)。目前关于丹江口水库鱼类的研究不多, 且仅限于鱼类种类组成(E.B.波鲁茨基等，1959; 袁 凤霞和黄道明, 1989; 伦峰等, 2016; 廖传松等, 2018), 丹江口大坝修建对鱼类资源的影响分析(余 志堂, 1982; 包洪福, 2013), 库区重要经济鱼类资源 及其历史变化(Yuan et al，2016)以及几种特定鱼类 的生物学特征(邢东耀和杨干荣，1992; 张家波, 1999; 杨战伟等, 2012)等, 缺乏对库区鱼类群落结 构特征及时空变化的研究。本文通过对丹江口水库 鱼类群落进行调查, 并结合历史数据, 以期了解丹 江口水库鱼类群落现状及变化趋势, 为丹江口水库 鱼类资源的保护和可持续利用提供科学依据。

\section{材料与方法}

\section{1 研究区域}

研究区域为丹江口水库主要库区。共选取河南 省淅川县马蹬镇、中线渠首，以及湖北省丹江口市 (坝前)、凉水河镇、均县镇等5个采样点(图1)。

\section{2 数据采集}

分别于2018年10月(秋季)、2019年1月(冬季)、 2019年4月(春季)、2019年7月(夏季)对丹江口水库进 行了鱼类群落调查, 采用刺网采样和渔民渔获物调 查两种方法进行，每个采样点每次调查持续3天 (次)。刺网采样采用多网目复合刺网进行, 每条多

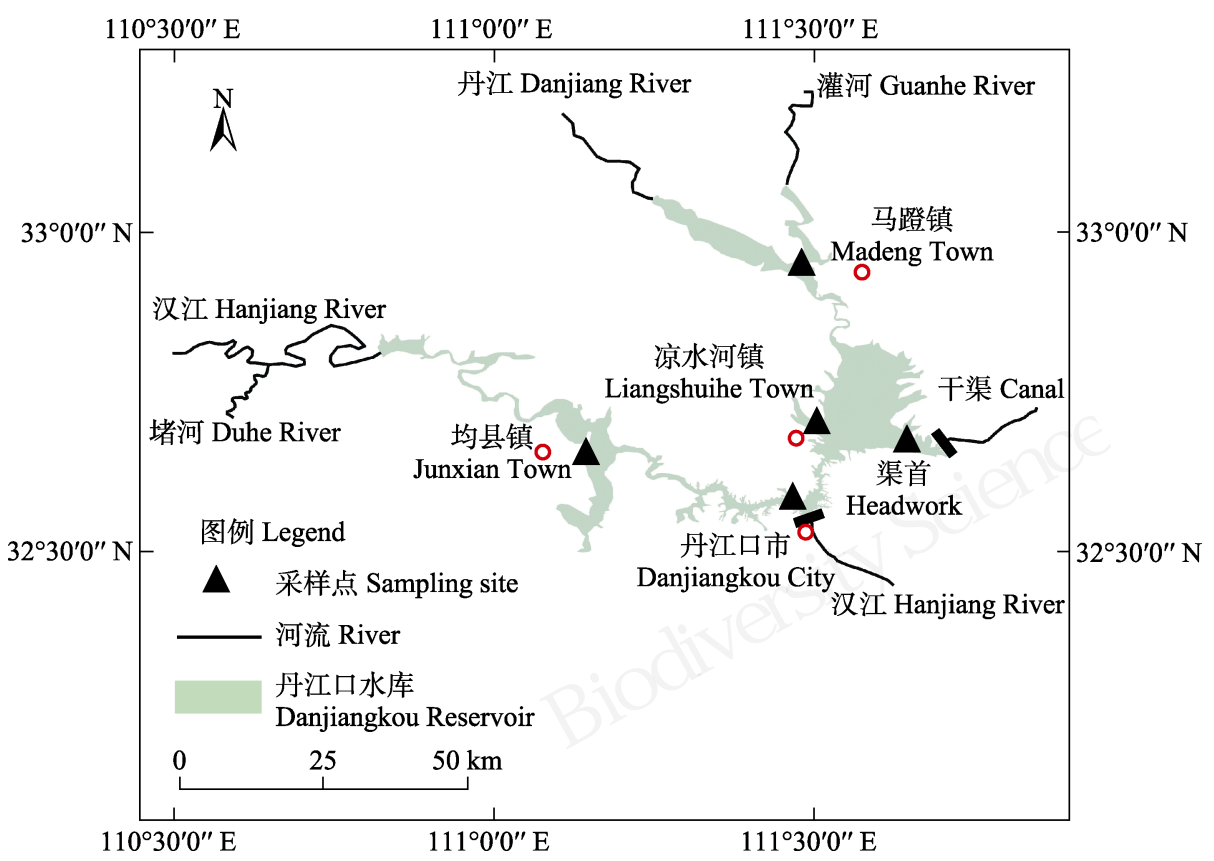

图 1 丹江口水库鱼类群落调查位点分布

Fig. 1 Distribution of sites for fish assemblage sampling in the Danjiangkou Reservoir 
网目复合刺网高 $3 \mathrm{~m}$, 长 $30 \mathrm{~m}$, 由 12 种网目的网片 拼接而成, 每种网目长度为 $2.5 \mathrm{~m}$, 网目大小分别为 $4.3 、 2.0 、 0.6 、 1.0 、 5.5 、 0.8 、 1.3 、 2.4 、 1.6 、 0.5 、$ $3.5 、 2.9 \mathrm{~cm}$ 。单次采样时间为18:00至次日6:00 (12 h), 各采样点敷设浮网和沉网各6条。刺网采样期间同 时开展渔民渔获物调查, 在渔船停靠密集的码头, 以船为单位进行渔具种类、数量、渔具敷设方法、 渔获物种类、数量与生物量调查。鱼类鉴定及种属 划分参照朱松泉(1995)、陈宜瑜(1998)、禇新洛等 (1999)和乐佩琦(2000), 个别鱼类(主要为外来养殖 逃逸鱼类)的物种鉴定及种属划分也参考了世界鱼 类数据库(https://www.fishbase.org/)。测量鱼类体长 和体重, 分别精确到 $1 \mathrm{~mm}$ 和 $0.01 \mathrm{~g}$ 。

\section{3 数据处理}

\subsection{1 群落多样性分析}

基于多网目复合刺网采样的鱼类群落多样性 采用物种丰富度指数 $(D$, 即单次采样采集的鱼类物 种数)、Shannon-Wiener多样性指数 $\left(H^{\prime}\right)$ (Ludwig \&
1975)、Pinkas相对重要性指数(IRI) (Pinkas et al, 1970)进行分析，计算公式如下：

$$
\begin{aligned}
& H^{\prime}=-\sum P_{i} \ln P_{i} \\
& J=H^{\prime} / \ln S \\
& I R I=(N \%+W \%) \times F \% \times 10000
\end{aligned}
$$

式中, $S$ 为群落中鱼类的总种数; $N$ 为群落中鱼类的 个体总数; $P_{i}$ 为群落中某一种鱼类个体数与鱼类总 个体数的比值, 即 $P_{i}=N_{i} / N$ 。W\%为群落中某一种鱼 类重量与鱼类总重量的比值, $F \%$ 为某一种鱼类出 现的采样点数与总采样点数的百分比, IRI $>1,000$ 为优势种, 100-1,000为重要种, 10-100为常见种, 1-10为一般种, $I R I<1$ 的为少见种。

\subsection{2 生态类型划分}

参照殷名称(1995), 将丹江口水库鱼类按营养 结构分为肉食性、植食性、杂食性3类。参考相关 文献(湖北省水生生物研究所鱼类研究室, 1976; 茹 辉军等, 2010; 贾银涛等, 2013), 将丹江口水库鱼类 按栖息类型分为上层、中层、底栖鱼类3种。参考 相关文献(湖北省水生生物研究所鱼类研究室, 1976; 陈锋等, 2012; 贾银涛等, 2013), 将丹江口水库鱼类 按照流水亲和性分为喜流水性鱼类和喜静缓水性 鱼类。依据殷名称(1995), 将丹江口水库鱼类按照洄 游习性分为洄游性鱼类和定居性鱼类。

\subsection{3 群落相似性分析}

采用Jaccard相似性指数(JSI) (Jaccard, 1912)对 采集的鱼类群落进行相似性分析。其计算公式为:

$$
J S I=\mathrm{c} /(\mathrm{a}+\mathrm{b}-\mathrm{c})
$$

式中, $a$ 和 $b$ 为 $A 、 B$ 两次调查采集鱼类的种数; $c$ 是 $A$ 、 $\mathrm{B}$ 两次采集的共有鱼类种数。当JSI的值在 $0-0.25$ 之 间时，为极不相似; 在0.25-0.50之间时，为中等不 相似; 在 0.50-0.75之间时，为中等相似; 在 0.75-1.00之间时，为极相似(Krebs, 1999)。

\section{4 统计分析}

各采样点间鱼类群落多样性差异检验采用单 因素方差分析 (One way ANOVA), 首先采用 Shaprio-Wilk test对各组数据进行正态性检验, 若不 正态则先进行 $\lg (\mathrm{x})$ 对数转换, 直至其符合正态分 布。然后采用最小显著性差异法(least significant difference, LSD test)进行多重比较。统计显著性水平 为 0.05 。统计分析软件为SPSS 20.0 。

\section{结果}

\section{1 鱼类群落现状}

\subsection{1 种类组成}

本次调查共采集到鱼类33种，隶属5目 11 科 29 属, 其中鲤形目 2 科 20 属 22 种, 鲇形目 3 科 3 属 5 种, 鲇形目 4 科4属4种，鲑形目、领针鱼目均为 1 科 1 属 1 种(附录1)。鲤科鱼类为丹江口水库鱼类的重要组成 部分, 物种数占比 $63.6 \%$, 其次为魭科鱼类, 物种数 占比 $9.1 \%$, 银鱼科、鳅科、鮰科、鲇科、鮨科、虾 虎鱼科、鳢科、太阳鱼科、鰔科物种数各占 $3.0 \%$ 。 空间上, 2018-2019年马蹬镇、渠首、凉水河、丹江 口市、均县镇5个采样点分别调查到鱼类16、19、 19、20、22种; 季节上，春季、夏季、秋季、冬季 分别调查到鱼类22、27、24、18种。

\subsection{2 生物多样性及单位努力捕捞量}

基于多网目复合刺网采样的丹江口水库鱼类群 落多样性指数、单位努力捕捞量如表1所示(各采样点 的数值为 4 个季节的平均值)。物种丰富度在空间上表 现为均县镇 $>$ 渠首 $>$ 凉水河镇 $>$ 丹江口市 $>$ 马 蹬镇, 季节上整体表现为夏秋高、春冬低; 多样性指 数在空间上也表现为均县镇 $>$ 渠首 $>$ 凉水河镇 $>$ 丹江口市 $>$ 马蹬镇, 季节上也整体呈现夏秋高、春 冬低的趋势; 均匀度指数在空间上表现为马蹬镇 > 均县镇 > 凉水河镇 > 丹江口市 > 渠首; 季节 
表1 基于多网目复合刺网采样的2018-2019年丹江口水库鱼类群落多样性指数及单位努力捕捞量的空间差异(不同小写字母 表示各地点间具有显著性差异)

Table 1 Spatial variations of biodiversity indexes and catch per unit effort (CPUE) of fish in the Danjiangkou Reservoir in 2018-2019 based on multi-mesh gillnet samplings. Different lowercase letters indicate the significant differences among sites.

\begin{tabular}{|c|c|c|c|c|c|}
\hline $\begin{array}{l}\text { 地点 } \\
\text { Sampling site }\end{array}$ & $\begin{array}{l}\text { 马蹬镇 } \\
\text { Madeng Town }\end{array}$ & $\begin{array}{l}\text { 丹江口市 } \\
\text { Danjiangkou City }\end{array}$ & $\begin{array}{l}\text { 凉水河镇 } \\
\text { Liangshuihe Town }\end{array}$ & $\begin{array}{l}\text { 渠首 } \\
\text { Headwork }\end{array}$ & $\begin{array}{l}\text { 均县镇 } \\
\text { Junxian Town }\end{array}$ \\
\hline 物种丰富度 Species richness $(D)$ & $7.000 \pm 0.892^{\mathrm{a}}$ & $8.000 \pm 1.033^{\mathrm{a}}$ & $8.000 \pm 0.813^{\mathrm{a}}$ & $10.000 \pm 0.433^{\mathrm{a}}$ & $12.000 \pm 1.031^{\mathrm{b}}$ \\
\hline $\begin{array}{l}\text { Shannon-Wiener多样性指数 Shannon-Wiener } \\
\text { diversity index }\left(H^{\prime}\right)\end{array}$ & $1.374 \pm 0.173^{\mathrm{a}}$ & $1.408 \pm 0.169^{\mathrm{a}}$ & $1.424 \pm 0.182^{\mathrm{a}}$ & $1.436 \pm 0.076^{\mathrm{a}}$ & $1.574 \pm 0.226^{\mathrm{a}}$ \\
\hline Pielou均匀度指数 Pielou evenness index $(J)$ & $0.769 \pm 0.067^{\mathrm{a}}$ & $0.636 \pm 0.083^{\mathrm{a}}$ & $0.641 \pm 0.069^{\mathrm{a}}$ & $0.614 \pm 0.037^{\mathrm{a}}$ & $0.644 \pm 0.070^{\mathrm{a}}$ \\
\hline 单位努力捕捞量 $C P U E\left(\mathrm{~g} \cdot \mathrm{day}^{-1} \cdot \mathrm{m}^{-2}\right)$ & $2.568 \pm 0.977^{\mathrm{a}}$ & $3.735 \pm 1.108^{\mathrm{ab}}$ & $3.846 \pm 1.112^{\mathrm{ab}}$ & $4.298 \pm 1.096^{\mathrm{ab}}$ & $4.841 \pm 0.586^{\mathbf{b}}$ \\
\hline
\end{tabular}

上整体为夏秋冬较高、春季低。单位努力捕捞量空 间上表现为均县镇 $>$ 渠首 $>$ 凉水河镇 $>$ 丹江 口市 >马蹬镇, 季节上呈现春夏秋较高、冬季低的 趋势。

另外, Pinkas相对重要性指数分析表明, 马蹬 镇的优势种为鲫 (Carassius auratus, $I R I=8,930$ )、红 鯺原鲌(Cultrichthys erythropterus, $I R I=8,397$ )、择 (Hemiculter leucisculus, IRI = 2,723)、太湖新银鱼 (Neosalanx taihuensis, IRI = 2,720)、尧嘴鲌(Culter alburnus, $I R I=1,349)$; 渠首的优势种头粲 $(I R I=$ $8,918)$ 、鲫 $(I R I=3,138)$ 、太湖新银鱼 $(I R I=1,234)$; 凉 水河的优势种为蒙古鲌(Culter mongolicus, IRI = $3,648)$ 、红鰖原鲌 $(I R I=1,021)$; 丹江口市的优势种 为蒙古鲌 $(I R I=5,116)$ 、駼 $(I R I=2,471)$ 、红鳍原鲌 $(I R I=1,725)$; 均县镇的优势种为鲫 $(I R I=3,722)$ 、银

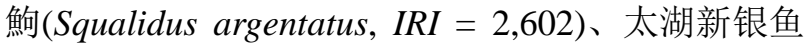
$(I R I=2,556)$ 、蒙古鲌 $(I R I=1,779) 、$ 蛇鮈(Saurogobio dabryi, $I R I=1,381)$ 。

\subsection{3 生态类型}

从营养结构上看, 丹江口水库的杂食性鱼类 $(16$ 种, $48.5 \%)=$ 肉食性鱼类 $(16$ 种, $48.5 \%)>$ 植食 性鱼类(1种, $3.0 \%)$; 从栖息类型上看, 中层鱼类(15 种, $45.5 \%)>$ 底层鱼类(12种, 36.4\%) > 上层鱼类(6 种, 18.2\%); 从流水亲和性上看, 喜静缓水性鱼类 (30种, 90.9\%) > 喜流水性鱼类(3种, 9.1\%); 从洄游 习性上看, 定居性鱼类 $(27$ 种, $81.8 \%)>$ 洄游性鱼类 (6种, 18.2\%)。目前丹江口水库以中下层、定居性、 喜静缓流、杂食性和肉食性鱼类为主(附录1)。

\section{2 历史变化}

\subsection{1 物种组成历史变化}

20 世纪50年代共调查到鱼类43种, 隶属7目 11 科36属(图2)。其中鲤科鱼类最多, 为28种, 占物种
总数的 $65.1 \%$; 鲿科、鮨科鱼类各3种，均占物种总 数的 $7.0 \%$; 平鯺鳅科鱼类共 2 种，占物种总数的 $4.7 \%$; 鲟科、鳀科、鳗鲭科、鲇科、合鳃鱼科、虾 虎鱼科、塘鳢科鱼类各1种，均占物种总数的 $2.3 \%$ (E.B.波鲁茨基等, 1959)。

20 世纪 80 年代共调查到鱼类 67 种，隶属 4 目 12 科53属(图2)。其中鲤科鱼类最多, 为43种, 占物种 总数的 $64.2 \%$; 魭科鱼类 9 种, 占物种总数的 $13.4 \%$; 鮨科、鳅科鱼类各3种，均占物种总数的 $4.5 \%$; 鲇科 2 种, 占物种总数的 $3.0 \%$; 平鯺鳅科、鮡科、合鳃鱼 科、刺鳅科、虾虎鱼科、鳢科、塘鳢科各 1 种, 均占 物种总数的 $1.5 \%$ (袁凤霞和黄道明, 1989)。

本次调查(2018-2019年)与20世纪80年代相比, 丹江口水库鱼类减少了 34 种, 其中鲤科鱼类减少了 24 种，魭科鱼类减少了 6 种，鮡科、刺鳅科、塘鳢科 鱼类均没有采集到; 新增太湖新银鱼、间下魾 (Hyporhamphus intermedius)、乐山小鳔鮈 (Microphysogobio kiatingensis), 以及外来网箱养殖 逃逸鱼类大口黑鲇(Micropterus salmoides)和斑点叉 尾鮰(Ictalurus punctatus)。与20世纪50年代相比, 丹 江口水库鱼类减少了 10 种, 其中鲤科鱼类减少了 7 种，鲟科、鳀科、鳗鳕科、平鯺鳅科等鱼类没有采 集到。 20 世纪 80 年代与 50 年代相比, 丹江口水库鱼 类增加了 24 种，其中鲤科鱼类增加了 14 种、鲿科增 加了6种，而鲟科、鳀科、鳗鲡科等鱼类消失。

本次调查(2018-2019年)与 20世纪80年代调查 共有鱼类 26 种，物种相似性指数为 0.35 , 为中等不 相似; 与 20 世纪 50 年代共有鱼类为 17 种, 物种相似 性指数为 0.29 , 为中等不相似; 20 世纪 50 年代和 80 年代调查共有鱼类 34 种, 相似性指数为 0.45 , 为中 等不相似(表2)。 


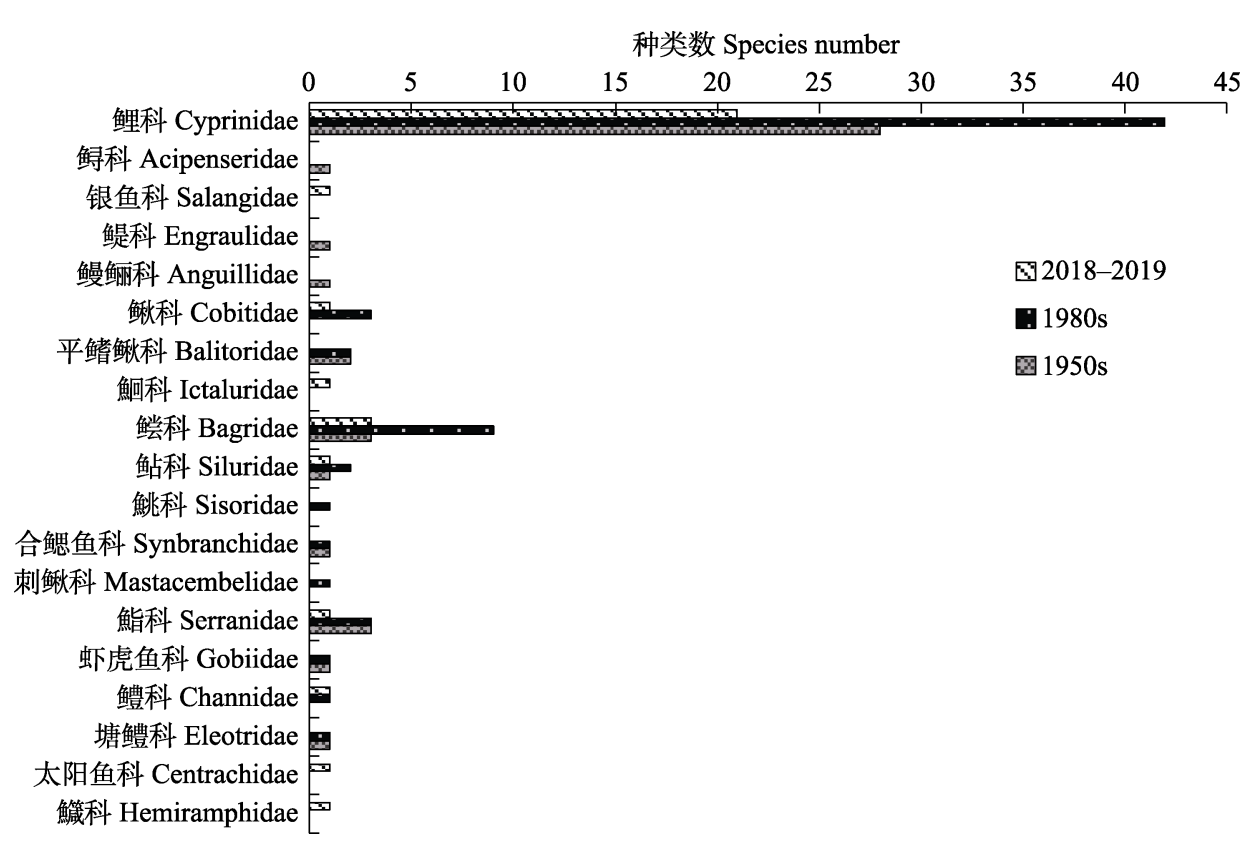

图2 丹江口水库不同时期鱼类种类组成

Fig. 2 Composition of fish species in different time periods in the Danjiangkou Reservoir

\subsection{2 生态类型历史变化}

丹江口水库鱼类群落生态类型变化如图3所示。

营养结构: 丹江口水库20世纪50年代杂食性鱼 类比例(26种, 60.5\%) (种类数和所占比例, 下同) > 肉食性鱼类 $(16$ 种, 37.2\%) > 植食性鱼类(1种, 2.3\%); 20 世纪80年代杂食性鱼类比例(39种，58.2\%) > 肉 食性鱼类(27种，40.3\%) > 植食性鱼类(1种，1.5\%); 本次调查(2018-2019年)杂食性鱼类比例 (16种, $48.5 \%)=$ 肉食性鱼类 $(16$ 种, $48.5 \%)>$ 植食性鱼类 (1种, 3.0\%)。20世纪50年代至今, 丹江口水库鱼类 营养结构呈现杂食性鱼类比例持续下降, 肉食性比 例持续上升的趋势, 植食性鱼类变化不大。

栖息类型: 丹江口水库20世纪50年代中层鱼类 (22种, 51.2\%) > 底栖鱼类(17种, 39.5\%) > 上层鱼 类 (4种, 9.3\%); 20 世纪 80 年代中层鱼类 (31 种, $46.3 \%)>$ 底栖鱼类(30种, 44.8\%) > 上层鱼类(6种, $9.0 \%)$; 本次调查(2018-2019年) 中层鱼类(14种, $42.4 \%)>$ 底栖鱼类(13种, 39.4\%) > 上层鱼类(6种, $18.2 \%) ; 3$ 个时期都以中层、底栖鱼类为主。

流水亲和性: 丹江口水库20世纪50年代喜静缓 水性鱼类(29种, 67.4\%) > 喜流水性鱼类(14种, $32.6 \%) ; 20$ 世纪 80 年代喜静缓水性鱼类 (50 种, 74.6\%) > 喜流水性鱼类(17种, 25.4\%); 本次调查 (2018-2019年)喜静缓水性鱼类(30种, 90.9\%) > 喜
流水性鱼类(3种, 9.1\%)。20世纪50年代至今, 丹江 口水库鱼类呈现喜流水性鱼类比例持续下降, 喜静 缓水性鱼类比例持续上升的趋势。

洄游习性: 丹江口水库20世纪50年代定居性鱼 类(29种, 67.4\%) > 洄游性鱼类(14种, 32.6\%); 20世 纪80年代定居性鱼类(55种, 82.1\%) > 洄游性鱼类 (12种, 17.9\%); 本次调查(2018-2019年)定居性鱼类 (27种, 81.8\%) > 洄游性鱼类(6种, 18.2\%)。20世纪50 年代至今, 洄游性鱼类种类数持续减少, 定居性鱼 类种类数持续增多。目前丹江口水库以定居性鱼类 为主。

\section{3 讨论}

\section{1 丹江口水库鱼类群落现状}

丹江口水库鱼类群落现状主要表现为以下几 个特征:

(1)物种丰富度低。本次调查(2018-2019年)采集 到鱼类33种，远少于伦峰等(2016)于2013-2014年在 河南库区调查到的62种，但略多于廖传松等(2018) 于2016年调查到的25种。少于伦峰等(2016)的原因 推测如下: (a)由于调查强度的原因, 部分不常见鱼 类在本次调查中没有采集到，如三角鲂 (Magalobrame tarminalis)、鲩(Ochetobibus elongatus)、尖头鲌(Culter oxycephalus)等; (b)伦峰等 
表2 丹江口水库不同时期鱼类组成相似性指数

Table 2 Variations of fish similarity index in different time periods in the Danjiangkou Reservoir

\begin{tabular}{|c|c|c|c|c|c|c|c|}
\hline \multirow[t]{2}{*}{ 科 Family } & \multicolumn{3}{|c|}{ 种类数 Species number } & \multirow{2}{*}{ 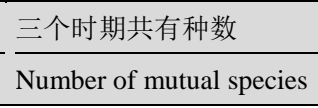 } & \multicolumn{3}{|c|}{ 相似性指数 Jaccard similarity index } \\
\hline & 195 & s 1980s & 2018-2019 & & 1950s vs. 1980 s & 1950s vs. 2018-2019 & 1980s vs. $2018-2019$ \\
\hline 鲤科 Cyprinidae & 28 & 42 & 21 & 12 & 0.46 & 0.36 & 0.43 \\
\hline 鲟科 Acipenseridae & 1 & 0 & 0 & 0 & 0.00 & 0.00 & 0.00 \\
\hline 银鱼科 Salangidae & 0 & 0 & 1 & 0 & 0.00 & 0.00 & 0.00 \\
\hline 鳀科 Engraulidae & 1 & 0 & 0 & 0 & 0.00 & 0.00 & 0.00 \\
\hline 鳗鳕科 Anguillidae & 1 & 0 & 0 & 0 & 0.00 & 0.00 & 0.00 \\
\hline 鳅科 Cobitidae & 0 & 3 & 1 & 0 & 0.00 & 0.00 & 0.33 \\
\hline 平鳀鳅科 Balitoridae & 2 & 2 & 0 & 0 & 1.00 & 0.00 & 0.00 \\
\hline 鮰科 Ictaluridae & 0 & 0 & 1 & 0 & 0.00 & 0.00 & 0.00 \\
\hline 鲿科 Bagridae & 3 & 9 & 3 & 3 & 0.33 & 0.20 & 0.33 \\
\hline 鲇科 Siluridae & 1 & 2 & 1 & 1 & 0.50 & 1.00 & 0.00 \\
\hline 鮡科 Sisoridae & 0 & 1 & 0 & 0 & 0.00 & 0.00 & 0.00 \\
\hline 合鳃鱼科 Synbranchidae & 1 & 1 & 0 & 0 & 1.00 & 0.00 & 0.00 \\
\hline 刺鳅科 Mastacembelidae & 0 & 1 & 0 & 0 & 0.00 & 0.00 & 0.00 \\
\hline 鮨科 Serranidae & 3 & 3 & 1 & 1 & 1.00 & 0.33 & 0.33 \\
\hline 虾虎鱼科 Gobiidae & 1 & 1 & 1 & 1 & 1.00 & 1.00 & 0.00 \\
\hline 鳢科 Channidae & 0 & 1 & 1 & 0 & 0.00 & 0.00 & 1.00 \\
\hline 塘鳢科 Eleotridae & 1 & 1 & 0 & 0 & 1.00 & 0.00 & 0.00 \\
\hline 太阳鱼科 Centrachidae & 0 & 0 & 1 & 0 & 0.00 & 0.00 & 0.00 \\
\hline 鱵科 Hemiramphidae & 0 & 0 & 1 & 0 & 0.00 & 0.00 & 0.00 \\
\hline 合计 Total & 43 & 67 & 33 & 18 & 0.45 & 0.29 & 0.35 \\
\hline
\end{tabular}
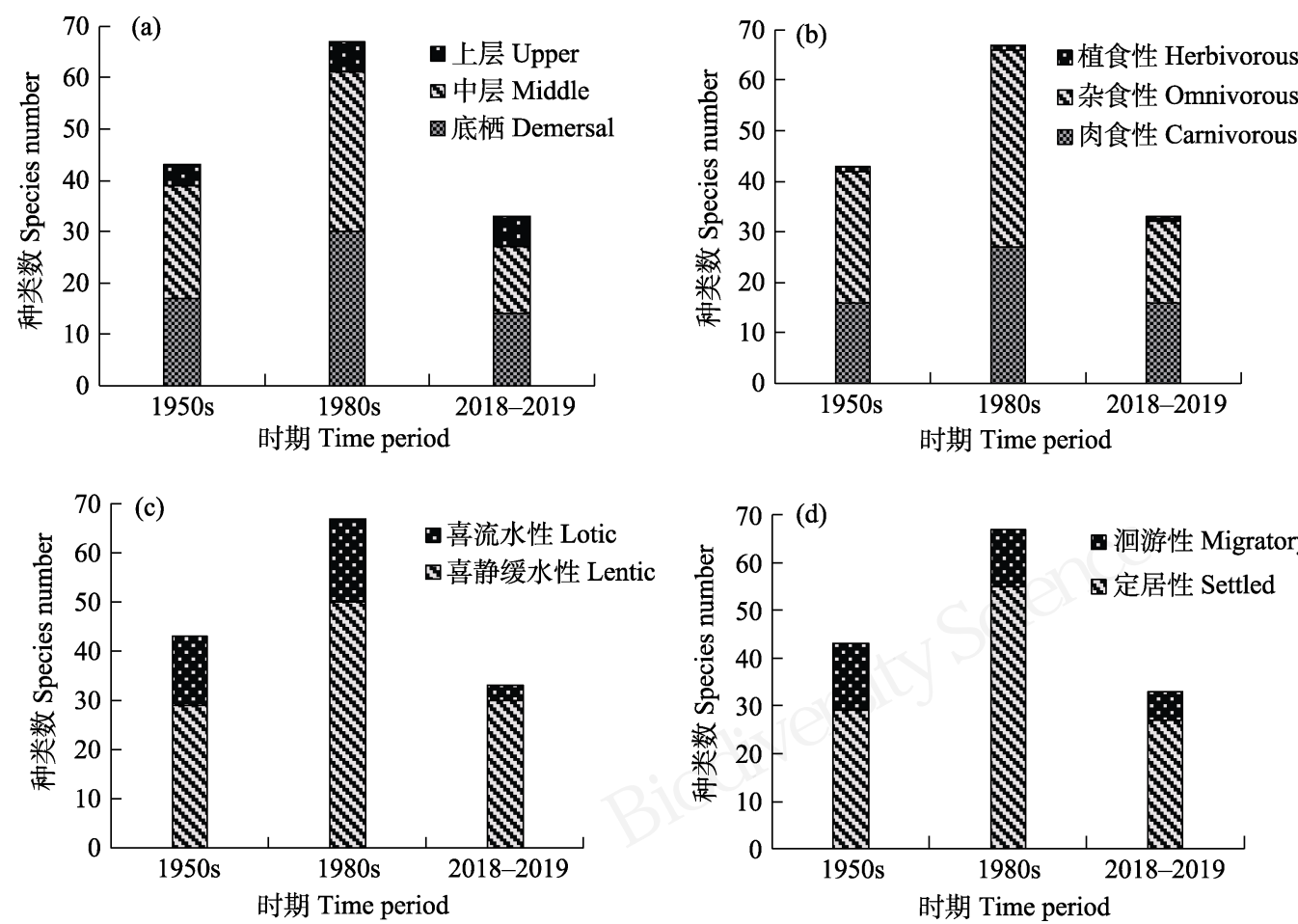

图 3 丹江口水库不同生态类型鱼类组成比例的时间变化

Fig. 3 Temporal variations of fish species proportional composition for different ecological types in the Danjiangkou Reservoir 
(2016)的工作中存在一些种属划分的争议, 以及某 些鱼由于古今异名被错划分为几种的情况, 例如大 鯺刺鰟鮍(Acanthorhodeus macropterus) 和大鯺䁤 (Acheilognathus macropterus) 在该研究中被划分为2 种不同的鱼; (c)伦峰等(2016)的研究主要集中在 2013-2014年，而2014年后水库再次加高蓄水位 (Pan et al, 2018), 导致库区流水生境进一步丧失, 部分鱼类 (特别是喜流水性鱼类如马口鱼 Opsariichthys bidens、宽鳍鱲 Zacco platypus等)在本 研究中没有采集到; (d)调查方法的不同可能也导致 了调查结果的差异, 该研究采用的撒网、迷魂阵等 渔具渔法可能对部分鱼类(尤其是不常见鱼类)的选 择性更低、捕捞效率更高。本研究调查到的鱼类种 类数略多于廖传松等(2018)的调查结果, 增加的种 类为中华花鳅 (Cobitis sinensis)、子陵吻虾虎鱼 (Rhinogobius giurinus) 等小型鱼类和大口黑鲈 (Micropterus salmoides)、斑点叉尾鮰 (Ictalurus punctatus)等外来鱼类, 其主要原因可能是本研究 的调查样点和调查次数略多于后者, 调查方法也相 对更为丰富(附录2)。

(2)鱼类个体趋向于小型化。相对重要性指数分 析表明目前丹江口水库主要优势鱼类为粲、鲫、鲤 (Cyprinus carpio)、红鯺原鲌、蒙古鲌、飘鱼 (Pseudolaubuca sinensis)等十几种鱼类，鱼类资源 存在小型化趋势。有研究认为鱼类资源小型化与人 类活动密切相关(徐姗楠等, 2019), 如大坝建设、过 度捕捞、小型鱼类引种、水域污染等(范振华等, 2012)。本研究中, 丹江口水利工程的修建、捕捞、 太湖新银鱼等小型鱼类的引入等可能是造成丹江 口水库鱼类小型化的原因。丹江口水库鱼类群落多 样性指数在0.94-2.25之间, 略低于Magurran (1989) 提出的多样性指数的一般范围(1.5-3.5), 表明目前 丹江口水库的鱼类多样性指数不高。同时, 丹江口 水库的Pielou均匀度指数也不高(0.5-0.91), 可能原 因是小型优势种如㱩、太湖新银鱼等的比例较高。

(3)群落多样性指数呈现一定的时空差异。空间 上, 渠首、凉水河、均县镇的物种丰富度指数、多 样性指数和单位努力捕捞量高于丹江口市和马蹬 镇。可能原因是库区水域开阔, 饵料资源丰富, 生 境异质性高, 适合鱼类生存; 而马蹬镇位于库区上 游, 丹江口市位于两个库区交汇处, 河面较窄, 两 处地点生境较为单一。季节上, 物种丰富度指数、
多样性指数和单位努力捕捞量一般表现为夏秋高、 春冬低。可能原因是夏秋季水温较高, 鱼类的快速 生长繁殖导致鱼类丰度相对较高 (Brandt, 1993; Wolter, 2007); 另一方面, 水温较高时鱼类通常更 为活跃(Johnson \& Kelsch, 1998), 因此被网具捕捞 的几率增加。

\section{2 丹江口水库鱼类群落历史变化}

丹江口水库鱼类群落历史变化的显著特征是 物种丰富度呈现先上升后下降的趋势。本次调查 (2018-2019年)仅采集到33种，远低于20世纪80年代 的 67 种，以及 20 世纪 50 年代的 43 种鱼类。

建坝前汉江、丹江及其支流上游江段多峡谷、 险滩、岩洞，且水流湍急，当时采集到的达氏鲟 (Acipenser dabryanus)、白甲鱼(Onychostoma sima)、 瓣结鱼(Tor (Foliter) brevifilis brevifilis)、中华倒刺鲃 (Spinibarbus sinensis)、吻鮈(Rhinogobio typus)、铜 鱼(Coreius heterodon)等喜流水性鱼类，以及鳗鲭 (Anguilla japonica)、银鲖(Xenocypris argentea)等洄 游性鱼类在本次调查中未发现。丹江口水库第一阶 段蓄水后, 建坝蓄水显著改变了丹江口水库部分水 体原有的环境条件，如水流、水温、水深、栖息地 等, 几处开阔水域已呈静水状态, 导致成库初期库 区生态位出现严重空缺, 特别是在静水状态的开阔 水域, 适应新环境的部分外来机会主义者迅速增殖 (Stanford et al, 1986; Roberts, 2001)，例如尧嘴鲌、蒙 古鲌、大鯺鱊、麦穗鱼(Pseudorasbora parva)、银鮈 等适应静缓水的鱼类。但另一方面，汉江、丹江上 游库段仍有一定流速，特别是在每年6月以后的洪 水期，水流陡增(袁凤霞和黄道明, 1989)。这些水生 态条件仍适合许多流水性鱼类生长、繁殖。因此，相 比于 20 世纪 50 年代, 80年代喜静缓水性鱼类大幅增 多, 但流水性鱼类依旧有较大比重(袁凤霞和黄道 明, 1989), 导致鱼类物种丰富度较高。

而库区大坝二次加高后(2012年), 坝高由原来 的162 $\mathrm{m}$ 升至176.6 m, 库区已几乎无流水生境; 2014年再次加高蓄水水位，导致库区面积进一步加 大，部分喜流水性鱼类繁殖摄食生境遭到破坏，进 一步改变了库区鱼类群落结构。导致库区喜流水性 鱼类基本绝迹，鱼类物种丰富度显著降低，广适性 鱼类及喜静缓水性鱼类比例上升。本研究调查发现 丹江口水库现以鲫、鲤、红鯺原鲌、翅嘴鲌等喜静 缓水鱼类和广适性鱼类为主, 同时鱼类群落在库区 
不同水域呈现同质化趋势(廖传松等, 2018)。

库区鱼类营养结构的多样性取决于不同种类 间的捕食、竞争及人为因素的影响(张国华和曹文 宣, 1997; 刘其根, 2005)。丹江口水库鱼类营养结构 呈现杂食性鱼类比例持续下降, 肉食性比例持续上 升的趋势, 植食性鱼类变化不大。杂食性鱼类持续 下降的可能原因是建坝后消失的杂食性鱼类多为 大 魦鳠 (Mystus macropterus) 、细 鳞斜 领鱽 (Xenocypris microlepis)、中华纹胸鮡(Glyptothorax sinensis)等喜流水性鱼类或洄游性鱼类; 肉食性鱼 类比例持续上升可能是因人类活动增多导致, 如 20 世纪90年代引入的太湖新银鱼(杨战伟等, 2012), 及 网箱养殖逃逸的大口黑鲈、斑点叉尾鮰等肉食性鱼 类(Yuan et al, 2016)。由于杂食性鱼类被认为是增加 水域食物网复杂性和调节水域生态系统的重要因 素(Petchey et al, 2004; Bruno \& O’Connor, 2005), 其 比例持续下降可能导致丹江口水库水生态系统复 杂度和稳定性降低。

丹江口水库喜流水性和洄游性鱼类比例的持 续下降则可能由人类活动特别是建坝所导致。大坝 的修建通常会导致生态环境改变、阻隔、生境破碎 化等一系列问题(常剑波等, 2008; Dugan et al, 2010)。丹江口水库建坝之前采集到的喜流水性和洄 游性鱼类如吻鮈、鳗鲟等在后来的两次调查中均未 发现, 而且本次采集到的喜流水性鱼类已经减少到 了 3 种, 洄游性鱼类种数减少到了 6 种。建坝前, 一 些江海洄游性鱼类可以正常生长, 在建坝后江海洄 游性鱼类逐渐减少。随着时间的流逝, 江海洄游的 通道彻底被阻, 使其不能洄游产卵, 一些遗留下来 的个体也因为无法繁衍而消亡。而且在汉江采集到 的江河洄游性鱼类, 如短领鲚 (Coilia brachygnathus)、达氏鲟等在后来的调查中都未出现, 一些鱼类也因为无法适应环境而逐渐消亡。与此相 反, 大坝修建后形成的库区生境导致喜静缓水鱼类 和定居性鱼类比例增加。

\section{3 丹江口水库鱼类群落变化原因分析}

我们认为造成丹江口水库鱼类群落变化的主 要原因有以下几方面:

(1)大坝建设。鱼类洄游通道被阻, 导致洄游性 鱼类大量减少, 部分已经消失。历史调查中丹江口 水库盛产的鯮(Luciobrama macrocephalus)、大鯺鳠、 宽鯺鱲、马口鱼, 在大坝建设初期还有少量存在,
而在本次调查中没有采集到。近半个世纪以来丹江 口水利工程的修建带来了巨大的经济效益，但同时 也对丹江口水库的生态系统造成了影响。水坝建设 阻碍了洄游通道, 改变了库区的水文状况, 破坏了 库区的自然环境，使库区鱼类的洄游产卵和生活习 性发生了改变(余志堂, 1982)。

(2)渔业放养。20世纪90年代初期，受到人类大 规模商业放养等活动的影响, 鲢、鳙、鲤、鲫等经 济鱼类数量和生物量明显增加, 丹江口水库渔产量 由1983年的20 kg/ha增长到2012年的75 kg/ha (Yuan et al, 2016)。这些放养的经济鱼类与库区的天然鱼 类竞争栖息地和饵料生物资源, 致使鱼类群落结构 进一步发生变化。

(3)不合理捕捞。近年来, 相关部门为了库区鱼 类资源的保护和可持续发展，实行了增殖放流、禁 渔期管理等措施，都起到了积极作用(包洪福, 2013)。但是本研究(2018-2019年)的数次野外调查 发现, 渔民偷捕、滥捕现象仍较为严重, 迷魂阵捕 鱼、电鱼等违禁渔具渔法仍偶有发生，致使丹江口 水库鱼类资源继续衰退。

(4)外来鱼类。丹江口水库从 20 世纪 80 年代末期 开始发展网箱养殖, 年产量由1983年的不足 $200 \mathrm{t}$ 迅速增长到2012年的超过30,000 t (Yuan et al, 2016)。虽然为了实施南水北调工程，网箱已于 2014 年年底前全部拆除，但由于网箱养殖的外来鱼类的 逃逸，库区自然水体中也存在相当比例的外来鱼 类。本次调查也采集到了部分网箱养殖逃逸鱼类， 如来自北美地区的大口黑鲈、斑点叉尾鮰等。另外, 丹江口水库于 20 世纪 90 年代引入太湖新银鱼, 现已 形成近3,000 t的种群规模(杨战伟等, 2012)。本次调 查的Pinkas相对重要性指数分析也表明太湖新银鱼 为丹江口水库的优势鱼类。一般来说，外来鱼类通 常会通过捕食(Yonekura et al，2007)、种间竞争 (Costedoat et al, 2005)、破坏栖息地(Kitchell et al, 1997)和传播疾病(Gozlan et al, 2005)等方式影响本 地物种和水生生态系统。因此, 外来鱼类可能也是 导致丹江口水库鱼类群落多样性下降的原因之一。

\section{参考文献}

Bao HF (2013) Influence Analysis on Biological Diversity of Danjiangkou Reservoir at the Middle Route South-to-North Water Transfer Project. PhD dissertation, Northeast Forestry University, Harbin. (in Chinese with English abstract) [包洪 
福 (2013) 南水北调中线工程对丹江口库区生物多样性 的影响分析. 博士学位论文, 东北林业大学, 哈尔滨.]

Bolotskiy EB, Wu XW, Bai GD, Ge MS, Wang QL, Wang SD, Chen SZ (1959) Hydrobiological survey of the region of the projected dam-reservoir of Danjiangkou, with propositions for fisheries management. Acta Hydrobiologica Sinica, (1), 33-56. (in Chinese with English abstract) [E.B.波鲁茨基, 伍献文, 白国栋, 戈敏生, 王乾麟, 王士达, 陈受忠 (1959) 丹江口水库库区水生生物调查和渔业利用的意 见. 水生生物学报, (1), 33-56.]

Brandt SB (1993) The effect of thermal fronts on fish growth: A bioenergetics evaluation of food and temperature. Estuaries, 16, 142-159.

Bruno JF, O’Connor MI (2005) Cascading effects of predator diversity and omnivory in a marine food web. Ecology Letters, 8, 1048-1056.

Chang JB, Chen YB, Gao Y, Zhu B, Qiao Y (2008) The influence of water conservancy and hydropower project on fish and countermeasures. In: Proceedings of the 2008 Annual Conference of Chinese Hydraulic Engineering Society (Vol. 1), pp. 685-696. China Water \& Power Press, Beijing. (in Chinese) [常剑波, 陈永柏, 高勇, 朱滨, 乔晔 (2008) 水利水电工程对鱼类的影响及减缓对策. 见: 中 国水利学会2008年学术年会论文集(上册), 685-696页. 中国水利水电出版社, 北京.]

Chen F, Zhao XF, Zhao JY, Li M (2012) Investigation of fish resources in the Oujiang River and its protection strategy. Resources and Environment in the Yangtze Basin, 21, 934-941. (in Chinese with English abstract) [陈锋, 赵先富, 赵进勇, 李敏 (2012) 瓯江鱼类资源调查及保护对策. 长 江流域资源与环境, 21, 934-941.]

Chen YY (1998) Fauna Sinica • Osteichthyes • Cypriniformes. II. Science Press, Beijing. (in Chinese) [陈宜瑜 (1998)中国 动物志 - 硬骨鱼纲 - 鲤形目 (中卷). 科学出版社, 北 京.]

Chu XL, Zheng BS, Dai DY (1999) Fauna Sinica - Osteichthyes - Siluriformes. Science Press, Beijing. (in Chinese) [褚新洛, 郑葆珊, 戴定远 (1999) 中国动物 志 - 硬骨鱼纲 - 鲇形目. 科学出版社, 北京.]

Costedoat C, Pech N, Salducci MD, Chappaz R, Gilles A (2005) Evolution of mosaic hybrid zone between invasive and endemic species of Cyprinidae through space and time. Biological Journal of the Linnean Society, 85, 135-155.

Drake M, Valley R (2005) Validation and application of a fish-based index of biotic integrity for small central Minnesota lakes. North American Journal of Fisheries Management, 25, 1095-1111.

Dugan PJ, Barlow C, Agostinho AA, Baran E, Cada GF, Chen DQ, Cowx GI, Ferguson JW, Jutagate TT, Marmulla G, Nestler J, Petrere M, Welcomme RL, Winemiller KO (2010) Fish migration, dams, and loss of ecosystem services in the Mekong basin. Ambio, 39, 344-348.

Fan ZH, Ba JW, Duan XB (2012) Studies on fish resources and species diversity in the middle reaches of the Yangtze River from Yichang to Chenglingji section. Freshwater Fisheries, 42, 20-25. (in Chinese with English abstract) [范振华, 巴 家文, 段辛斌 (2012) 长江宜昌至城陵矶江段鱼类资源 现状及物种多样性研究. 淡水渔业, 42, 20-25.]

Fish Laboratory of Institute of Hydrobiology in Hubei Province (1976) Yangtze River Fish. Science Press, Beijing. (in Chinese) [湖北省水生生物研究所鱼类研究室 (1976) 长 江鱼类. 科学出版社, 北京.]

Fu JJ, Wang ML, Wang BH, Xie DX (2015) Operational management of Danjiangkou hydro-complex and its heightening works. Yangtze River, 46(6), 14-16. (in Chinese with English abstract) [付建军, 王梦凉, 王保红, 谢丹雄 (2015) 丹江口大坝加高施工和枢纽运行管理. 人民长江, 46(6), 14-16.]

Gozlan RE, St-Hilaire S, Feist SW, Martin P, Kent ML (2005) Biodiversity: Disease threat to European fish. Nature, 435, 1046.

Jaccard P (1912) The distribution of flora in the alpine zone. New Phytologist, 11, 37-50.

Jia YT, Chen YF, Tao J, He DK (2013) Current status and historical changes in fish assemblages of the Zengjiang River. Resources Science, 35, 1490-1498. (in Chinese with English abstract) [贾银涛, 陈毅峰, 陶捐, 何德奎 (2013) 增江鱼类群落特征及其历史变化. 资源科学, 35, 1490-1498.]

Johnson JA, Kelsch SW (1998) Effects of evolutionary thermal environment on temperature-preference relationships in fishes. Environmental Biology of Fishes, 53, 447-458.

Kitchell JF, Schindler DE, Ogutu-Ohwayo R, Reinthal PN (1997) The Nile perch in Lake Victoria: Interactions between predation and fisheries. Ecological Applications, 7, 653-664.

Krebs CJ (1999) Ecological Methodology. Harper Collins, New York.

Liao CS, Xiong MT, Yin Z, Liu JS (2018) Studies on the fishery fishing and community structure of fish in the Danjiangkou Reservoir. Journal of Anhui Agricultural Sciences, 46, 87-90. (in Chinese with English abstract) [廖 传松, 熊满堂, 殷战, 刘家寿 (2018) 丹江口水库渔业捕 捞及鱼类群落结构研究. 安徽农业科学, 46, 87-90.]

Liu QG (2005) Aquatic Environmental Protection Oriented Fishery in Lake Qiandaohu and Its Influences on Lake Ecosystem. PhD dissertation, East China Normal University, Shanghai. (in Chinese with English abstract) [刘其根 (2005) 千岛湖保水渔业及其对湖泊生态系统的影响. 博 士学位论文, 华东师范大学, 上海.]

Ludwig JA, Reynolds JF (1988) Statistical Ecology: A Primer on Methods and Computing. John Wiley \& Sons, New York.

Lun F, Li Z, Zhou BX, Wang CX, Li YY (2016) Investigation of fish resources in Danjiangkou Reservoir in Henan 
Province. Journal of Henan Agricultural Sciences, 45, 150-155. (in Chinese with English abstract) [伦峰, 李峥, 周本翔, 王晨溪, 李玉英 (2016) 丹江口水库(河南辖区) 鱼类资源调查. 河南农业科学, 45, 150-155.]

Lyons J, Gutiérrez-Hernández A, Díaz-Pardo E, Soto-Galera E, Medina-Nava M, Raúl PL (2000) Development of a preliminary index of biotic integrity (IBI) based on fish assemblages to assess ecosystem condition in the lakes of central Mexico. Hydrobiologia, 418, 57-72.

Magurran AE (1989) Ecological diversity and its measurement. Biometrics, 46, 81-99.

Pan YD, Guo SJ, Li YY, Yin W, Qi PC, Shi JW, Hu LQ, Li B, Bi SG, Zhu JY (2018) Effects of water level increase on phytoplankton assemblages in a drinking water reservoir. Water, 10, 256-274.

Petchey OL, Downing AL, Mittelbach GG, Persson L, Steiner CF, Warren PH (2004) Species loss and the structure and functioning of multitrophic aquatic systems. Oikos, 104, 467-478.

Pielou EC (1975) Ecological Diversity. John Wiley \& Sons, New York.

Pinkas L, Oliphant MS, Iverson LK (1970) Food habits of albacore, bluefin tuna, and bonito in California waters. Scripps Institution of Oceanography Library. Fish Bulletin, 152, 1-105.

Roberts TR (2001) On the river of no returns: Thailand's Pak Mun Dam and its fish ladder. Natural History Bulletin of the Siam Society, 492, 189-230.

Ru HJ, Wang HJ, Zhao WH, Shen YQ, Wang Y, Zhang XK (2010) Fishes in the mainstream of the Yellow River: Assemblage characteristics and historical changes. Biodiversity Science, 18, 179-186. (in Chinese with English abstract) [茹辉军, 王海军, 赵伟华, 沈亚强, 王勇, 张晓 可 (2010) 黄河干流鱼类群落特征及其历史变化. 生物 多样性, 18, 179-186.]

Stanford JA, Ward JV, Zimmermann HJ, Cline LD (1986) Fish of the Colorado River system. In: The Ecology of River Systems (eds Davies BR, Walker KF), pp. 385-402. Dr W. Junk Publishers, Dordrecht.

Vehanen T, Sutela T, Korhonen H (2010) Environmental assessment of boreal rivers using fish data-A contribution to the Water Framework Directive. Fisheries Management \& Ecology, 17, 165-175.

Wolter C (2007) Temperature influence on the fish assemblage structure in a large lowland river, the lower Oder River, Germany. Ecology of Freshwater Fish, 16, 492-503.

Xing DY, Yang GR (1992) The diet of six fierce fish in Danjiangkou Reservoir. Fishery of Water Conservancy, (3), 10-14. (in Chinese with English abstract) [邢东耀, 杨干荣 (1992) 丹江口水库六种凶猛鱼的食性. 水利渔业, (3), 10-14.]

Xu SN, Guo JZ, Chen ZZ, Zhang K, Xu YW, Cai YC, Li CH (2019) Tempo-spatial distribution characteristics of fish resources in Jiaozhou Bay. Journal of Fisheries of China, 43, 1615-1625. (in Chinese with English abstract) [徐姗楠, 郭 建忠, 陈作志, 张鬼, 许友伟, 蔡研聪, 李纯厚 (2019) 胶州湾鱼类资源量的时空分布特征. 水产学报, 43, 1615-1625.]

Yang ZW, Li ZJ, Liu JS, Zhang TL, Ye SW, Zhang H (2012) A comparative study on reproductive characteristics of different spawning stocks of the icefish (Neosalanx taihuensis) in the Danjiangkou Reservoir. Freshwater Fisheries, 42, 58-62. (in Chinese with English abstract) [杨 战伟, 李钟杰, 刘家寿, 张堂林, 叶少文, 张华 (2012) 丹江口水库太湖新银鱼不同繁殖群体的繁殖特征比较. 淡水渔业, 42, 58-62.]

Yin MC (1995) Fish Ecology. China Agriculture Press, Beijing. (in Chinese) [殷名称 (1995) 鱼类生态学. 中国农业出版 社, 北京.]

Yonekura R, Kohmatsu Y, Yuma M (2007) Difference in the predation impact enhanced by morphological divergence between introduced fish populations. Biological Journal of the Linnean Society, 91, 601-610.

Yu ZT (1982) Investigation of fish resources in the middle and lower reaches of the Hanjiang River and the impact assessment of the Danjiangkou water conservancy project on fish resources in the Hanjiang River. Fishery of Water Conservancy, (1), 19-27. (in Chinese with English abstract) [余志堂 (1982) 汉江中下游鱼类资源调查以及丹江口水 利枢纽对汉江鱼类资源影响的评价. 水库渔业, (1), 19-27.]

Yuan FX, Huang DM (1989) Analysis of fish resources and composition in the Danjiangkou Reservoir. Fishery of Water Conservancy, (2), 35-36. (in Chinese with English abstract) [袁凤霞, 黄道明 (1989) 丹江口水库鱼类资源及组成分 析. 水利渔业, (2), 35-36.]

Yuan J, Xia YG, Li ZJ, Yin Z, Liu JS (2016) Changes in fisheries resources in the Hanjiang River and Danjiangkou Reservoir, China. American Fisheries Society Symposium, 84, 179-191.

Yue PQ (2000) Fauna Sinica • Osteichthyes • Cypriniformes. III. Science Press, Beijing. (in Chinese) [乐佩琦 (2000) 中 国动物志 - 硬骨鱼纲 - 鲤形目 (下卷). 科学出版社, 北 京.]

Zhang GH, Cao WX (1997) Effects of fish stocking on lake ecosystems in China. Acta Hydrobiologica Sinica, 21, 271-280. (in Chinese with English abstract) [张国华, 曹文 宣 (1997) 湖泊放养渔业对我国湖泊生态系统的影响. 水生生物学报, 21, 271-280.]

Zhang JB (1999) Analysis of clustering on growth of predatory fish guild in the Danjiangkou Reservoir. Acta Hydrobiologica Sinica, 23, 689-695. (in Chinese with English abstract) [张家波 (1999) 丹江口水库凶猛鱼集团 生长特性组型的聚类分析. 水生生物学报, 23, 689-695.]

Zhang QF, Su RH, Jiang MX, Li SY (2007) The South-to-north Water Transfer Project and its ecological security: The 
priorities. Resources and Environment in the Yangtze Basin, 16, 217-221. (in Chinese with English abstract) [张全发, 苏荣辉, 江明喜, 李思悦 (2007) 南水北调工程及其生态 安全: 优先研究领域. 长江流域资源与环境, 16 , 217-221.]

Zhu SQ (1995) Synopsis of Freshwater Fishes of China.
Jiangsu Science and Technology Publishing House, Nanjing. (in Chinese) [朱松泉 (1995) 中国淡水鱼类检索表. 江苏 科技出版社, 南京.]

\section{(责任编委: 陈小勇 责任编辑: 间文杰)}

\section{附录 Supplementary Material}

附录1 丹江口水库不同时期鱼类名录及生态类型

Appendix 1 List and ecological types of fish species in different time periods in the Danjiangkou Reservoir http://www.biodiversity-science.net/fileup/PDF/2020009-1.pdf

\section{附录 2 伦峰等(2016)、廖传松等(2018)和本研究鱼类组成差异及成因分析}

Appendix 2 Differences of fish composition with cause analysis among Lun et al (2016), Liao et al (2018) and the present study http://www.biodiversity-science.net/fileup/PDF/2020009-2.pdf 
白敬沛, 黄耿, 蒋长军, 章伟成, 王齐东, 姚伦广 (2020) 丹江口水库鱼类群落特征及其历史变化. 生物多样性, 28, 1202-1212. http://www.biodiversity-science.net/CN/10.17520/biods.2020009

附录1 丹江口水库不同时期鱼类名录及生态类型。U: 上层; M: 中层; D: 底栖; C: 肉食性; H: 植食性; O: 杂食性; LO: 喜 流水性; LE: 喜静缓水性; MI: 洄游性; SE：定居性。

Appendix 1 List and ecological types of fish species in different time periods in the Danjiangkou Reservoir. U, Upper; M, Middle; D, Demersal; C, Carnivorous; H, Herbivorous; O, Omnivorous; LO, Lotic; LE, Lentic; MI, Migratory; SE, Settled.

\begin{tabular}{cllllll}
\hline 种 Species & 1950s & 1980s & $2013-2014$ & 2017 & $2018-2019$ & 生态类型 \\
& (E.B.波鲁茨基 & (袁风霞等, & (伦峰等, & (廖传松等, & (本研究) & Ecological type \\
& 等, 1958) & $1989)$ & 2016) & 2018) & & \\
\hline
\end{tabular}

\section{I 鲟形目 Acipenseriformes}

(一)鲟科 Acipenseridae

1. 达氏鲟 Acipenser dabryanus

\section{II 鲑形目 Salmoniformes}

(二)银鱼科 Salangidae

2. 太湖新银鱼 Neosalanx taihuensis

3. 长江银鱼 Hemisalanx

brachyrostralis

4. 寡齿短吻银鱼 Neosalanx oligodoitis

\section{III 鲱形目 Clupeiformes}

(三)鳀科 Engraulidae

5. 短领鲚 Coilia brachygnathus

IV 鳗鲟目 Anguilliformes

(四)鳗鲭科 Anguillidae

6. 鳗鲟 Anguilla japonica

V 鲤形目 Cypriniformes

(五)鲤科 Cyprinidae

7. 宽鯺鯔 Zacco platypus

8. 马口鱼 Opsariichthys bidens

9. 中华细鲫 Aphyocypris chinensis

10. 青鱼 Mylopharyngodon piceus

11. 草鱼 Ctenopharyngodon idellus

12. 赤眼鳟 Squaliobarbus curriculus

13. 鲩管 Ochetobibus elongatus

14. 鯮 Luciobrama macrocephalus

15. 鱤 Elopichthys bambusa

16. 飘鱼 Pseudolaubuca sinensis

17. 粲 Hemiculter leucisculus

18. 贝氏粲 Hemiculter bleekeri

19. 似鱎 Toxabramis swinhonis

20. 红鯺原鲌 Cultrichthys

erythropterus

21. 尧嘴鲌 Culter alburnus

22. 蒙古鲌 Culter mongolicus

23. 达氏鲌 Culter dabryi

24. 尖头鲌 Culter oxycephalus

25. 青梢红鲌 Erythroculter dabryi
$+$

$+$
C U LE SE

C U LE SE

C U LE SE

C U LO MI

O M LO SE

C M LO SE

O M LE SE

C D LE MI

H M LE MI

O M LE MI

O M LE MI

C M LE MI

C M LO MI

O U LE SE

O U LE SE

O U LE SE

O M LE SE

C M LE SE

C M LE SE

C M LE SE

C M LE SE

C M LE SE

C M LE SE 
白敬沛, 黄耿, 蒋长军, 章伟成, 王齐东, 姚伦广 (2020) 丹江口水库鱼类群落特征及其历史变化. 生物多样性, 28, 1202-1212. http://www.biodiversity-science.net/CN/10.17520/biods.2020009

\begin{tabular}{|c|c|c|c|c|c|c|c|c|c|}
\hline 种 Species & $\begin{array}{l}\text { 1950s } \\
\text { (E.B.波鲁茨基 }\end{array}$ & $\begin{array}{l}\text { 1980s } \\
\text { (袁凤霞等, }\end{array}$ & $\begin{array}{l}\text { 2013-2014 } \\
\text { (伦峰等, }\end{array}$ & $\begin{array}{l}2017 \\
\text { (廖传松等, }\end{array}$ & $\begin{array}{l}2018-2019 \\
\text { (本研究) }\end{array}$ & \multicolumn{3}{|c|}{$\begin{array}{l}\text { 生态类型 } \\
\text { Ecological type }\end{array}$} & \\
\hline 26. 拟尖头鲌 Culter oxycephaloides & & + & & & & $\mathrm{C}$ & M & LE & SE \\
\hline 27. 鳊 Parabramis pekinensis & + & + & + & & & $\mathrm{O}$ & $\mathrm{U}$ & LE & SE \\
\hline 28. 团头鲂 Megalobrama amblycephala & & + & + & & + & $\mathrm{O}$ & M & $\mathrm{LE}$ & SE \\
\hline 29. 三角鲂 Magalobrame tarminalis & & & + & & & $\mathrm{O}$ & M & LE & SE \\
\hline 30. 鲂 Megalobrama skolkovii & & + & & & & $\mathrm{O}$ & M & LE & SE \\
\hline 31. 银鲴 Xenocypris argentea & + & & + & & & $\mathrm{O}$ & M & LE & MI \\
\hline 32. 细鳞斜领鱽 Xenocypris microlepis & & + & + & & & $\mathrm{O}$ & M & LO & MI \\
\hline 33. 圆吻鲖 Distoechodon tumirostris & & + & + & & & $\mathrm{O}$ & M & LO & MI \\
\hline 34. 似鳊 Pseudobrama simoni & & + & & + & + & $\mathrm{O}$ & $\mathrm{U}$ & LE & SE \\
\hline 35. 鲢 Hypophthalmichthys molitrix & + & + & + & + & + & $\mathrm{O}$ & M & LE & MI \\
\hline 36. 鳙 Aristichthys nobilis & + & + & + & + & + & $\mathrm{O}$ & M & LE & MI \\
\hline 37. 唇䱻 Hemibarbus labeo & + & + & + & & & $\mathrm{O}$ & M & LO & SE \\
\hline 38. 花䱻 Hemibarbus maculatus & + & + & + & & & $\mathrm{O}$ & M & LO & SE \\
\hline 39. 麦穗鱼 Pseudorasbora parva & & + & + & & + & $\mathrm{O}$ & $\mathrm{U}$ & LE & SE \\
\hline $\begin{array}{l}\text { 40. 黑鯺鰁 Sarcocheilichthys } \\
\text { nigripinnis }\end{array}$ & & + & + & & & $\mathrm{O}$ & M & LE & SE \\
\hline $\begin{array}{l}\text { 41. 嘉陵领须鮈 } \\
\text { Gnathopogon herzensteini }\end{array}$ & & + & & & & $\mathrm{O}$ & M & LO & SE \\
\hline 42. 银鮈 Squalidus argentatus & & + & + & + & + & $\mathrm{O}$ & $\mathrm{D}$ & LE & SE \\
\hline 43. 铜鱼 Coreius heterodon & + & + & + & & & $\mathrm{O}$ & $\mathrm{D}$ & LO & MI \\
\hline 44. 圆筒吻鮈 Rhinogobio cylindricus & & + & & & & $\mathrm{O}$ & $\mathrm{D}$ & LO & MI \\
\hline 45. 吻鮈 Rhinogobio typus & + & & + & & & $\mathrm{O}$ & $\mathrm{D}$ & LO & SE \\
\hline 46. 棒花鱼 Abbottina rivularis & & + & + & & & $\mathrm{O}$ & $\mathrm{D}$ & LE & SE \\
\hline $\begin{array}{l}\text { 47. 乐山小鳔鮈 Microphysogobio } \\
\text { kiatingensis }\end{array}$ & & & & & + & $\mathrm{O}$ & $\mathrm{D}$ & LO & SE \\
\hline 48. 似鮈 Pseudogobio vaillanti & + & + & + & & & $\mathrm{O}$ & $\mathrm{D}$ & LO & SE \\
\hline 49. 蛇鮈 Saurogobio dabryi & + & + & + & & + & $\mathrm{O}$ & $\mathrm{D}$ & $\mathrm{LE}$ & SE \\
\hline $\begin{array}{l}\text { 50. 南方长须䱃鮀 Gobiobotia } \\
\text { longibarba meridionalis }\end{array}$ & & + & & & & $\mathrm{O}$ & $\mathrm{D}$ & LE & SE \\
\hline 51. 大鳍䁤 Acheilognathus macropterus & & + & + & & + & $\mathrm{O}$ & M & LE & SE \\
\hline 52. 彩副鱊 Paracheilognathus imberbis & & + & + & & & $\mathrm{O}$ & M & $\mathrm{LE}$ & SE \\
\hline 53. 高体鰟鮍 Rhodeus ocellatus & + & + & & & & $\mathrm{O}$ & M & LE & SE \\
\hline 54. 中华倒刺鲃 Spinibarbus sinensis & + & & & & & $\mathrm{O}$ & $\mathrm{D}$ & LE & SE \\
\hline $\begin{array}{l}\text { 55. 多鳞白甲鱼 Onychostoma } \\
\text { macrolepis }\end{array}$ & + & + & & & & $\mathrm{O}$ & $\mathrm{D}$ & LO & SE \\
\hline 56. 白甲鱼 Onychostoma sima & + & & & & & $\mathrm{O}$ & $\mathrm{D}$ & LO & MI \\
\hline $\begin{array}{l}\text { 57. 瓣结鱼 Tor (Foliter) brevifilis } \\
\text { brevifilis }\end{array}$ & + & & & & & $\mathrm{O}$ & $\mathrm{D}$ & LE & SE \\
\hline 58. 鲤 Cyprinus carpio & + & + & + & + & + & $\mathrm{O}$ & M & LE & SE \\
\hline $\begin{array}{l}\text { 59. 鲫 Carassius auratus } \\
\text { (六)鳅科 Cobitidae }\end{array}$ & + & + & + & + & + & $\mathrm{O}$ & M & LE & SE \\
\hline 60. 紫薄鳅 Leptobotia taeniaps & & + & & & & $\mathrm{O}$ & $\mathrm{D}$ & LO & SE \\
\hline 61. 中华花鳅 Cobitis sinensis & & + & + & & + & $\mathrm{O}$ & $\mathrm{D}$ & LE & SE \\
\hline 62. 泥鳅 Misgurnus anguillicaudatus & & + & + & & & $\mathrm{O}$ & $\mathrm{D}$ & LE & SE \\
\hline
\end{tabular}


白敬沛, 黄耿, 蒋长军, 章伟成, 王齐东, 姚伦广 (2020) 丹江口水库鱼类群落特征及其历史变化. 生物多样性, 28, 1202-1212. http://www.biodiversity-science.net/CN/10.17520/biods.2020009

\begin{tabular}{|c|c|c|c|c|c|c|c|c|c|}
\hline 种 Species & $\begin{array}{l}\text { 1950s } \\
\text { (E.B.波鲁茨基 }\end{array}$ & $\begin{array}{l}\text { 1980s } \\
\text { (袁凤霞等, }\end{array}$ & $\begin{array}{l}\text { 2013-2014 } \\
\text { (伦峰等, }\end{array}$ & $\begin{array}{l}2017 \\
\text { (廖传松等, }\end{array}$ & $\begin{array}{l}2018-2019 \\
\text { (本研究) }\end{array}$ & \multicolumn{4}{|c|}{$\begin{array}{l}\text { 生态类型 } \\
\text { Ecological type }\end{array}$} \\
\hline 63. 花斑副沙鳅 Parabotia fascoata & & & + & & & $\mathrm{O}$ & D & LE & SE \\
\hline $\begin{array}{l}\text { 64. 大鳞副泥鳅 Paramis-gurnus } \\
\text { dabryannus } \\
\text { (七)平鳍鲉科 Balitoridae }\end{array}$ & & & + & & & $\mathrm{O}$ & $\mathrm{D}$ & LE & SE \\
\hline 65. 犁头鳅 Lepturichthys fimbriata & + & + & & & & $\mathrm{O}$ & $\mathrm{D}$ & LO & SE \\
\hline
\end{tabular}

\section{VI 鲇形目 Siluriformes}

(八)鮰科 Ictaluridae

66. 斑点叉尾鮰 Ictalurus punctatus

\begin{tabular}{|c|c|c|c|c|c|c|c|c|}
\hline & & & & + & $\mathrm{C}$ & $\mathrm{D}$ & LE & SE \\
\hline \multirow[t]{3}{*}{+} & + & + & + & + & $\mathrm{C}$ & $\mathrm{D}$ & LE & SE \\
\hline & + & + & + & + & $\mathrm{C}$ & $\mathrm{D}$ & LE & SE \\
\hline & + & + & + & + & $\mathrm{C}$ & $\mathrm{D}$ & LE & SE \\
\hline \multirow[t]{5}{*}{+} & + & + & & & $\mathrm{C}$ & $\mathrm{D}$ & LO & SE \\
\hline & + & & & & $\mathrm{C}$ & $\mathrm{D}$ & LE & SE \\
\hline & + & & & & $\mathrm{C}$ & $\mathrm{D}$ & LE & SE \\
\hline & + & & & & $\mathrm{C}$ & $\mathrm{D}$ & LE & SE \\
\hline & + & & & & $\mathrm{C}$ & $\mathrm{D}$ & LE & SE \\
\hline+ & + & + & & & $\mathrm{C}$ & $\mathrm{D}$ & LO & SE \\
\hline \multirow[t]{4}{*}{+} & + & + & & + & $\mathrm{C}$ & $\mathrm{D}$ & LE & SE \\
\hline & + & & + & & $\mathrm{C}$ & $\mathrm{D}$ & LE & SE \\
\hline & & + & & & $\mathrm{C}$ & $\mathrm{D}$ & LE & SE \\
\hline & + & & & & $\mathrm{O}$ & $\mathrm{D}$ & LO & SE \\
\hline
\end{tabular}

79. 中华纹胸鮡 Glyptothorax sinensis

VII 合鳃鱼目 Synbranchiformes

(十二)合鳃鱼科 Synbranchidae

80. 黄鳝 Monopterus albus

VIII 鲇形目 Perciformes

(十三)鮨科 Serranidae

81. 鳜 Siniperca chuatsi

82. 大眼鳜 Siniperca kneri

83. 班鲭 Siniperca scherzeri

(十四)虾虎鱼科 Gobiidae

84. 子陵吻虾虎鱼 Rhinogobius giurinus

(十五)鳢科 Channidae

85. 乌鳢 Channa argus

(十六)刺鳅科 Mastacembelidae

86. 刺鳅 Mastacembelus aculeatus

(十七)塘鳢科 Eleotridae 
白敬沛, 黄耿, 蒋长军, 章伟成, 王齐东, 姚伦广 (2020) 丹江口水库鱼类群落特征及其历史变化. 生物多样性, 28, 1202-1212. http://www.biodiversity-science.net/CN/10.17520/biods.2020009

\begin{tabular}{|c|c|c|c|c|c|c|c|c|c|}
\hline \multirow{2}{*}{$\begin{array}{c}\text { 种 Species } \\
\text { 87. 小黄䱂鱼 Micropercops swinhonis }\end{array}$} & \multirow{2}{*}{$\begin{array}{l}\text { 1950s } \\
\text { (E.B.波鲁茨基 } \\
\text { 等, 1958) } \\
+\end{array}$} & \multirow{2}{*}{$\begin{array}{l}\text { 1980s } \\
\text { (袁凤霞等, } \\
\text { 1989) } \\
+\end{array}$} & \multirow{2}{*}{$\begin{array}{l}2013-2014 \\
\text { (伦峰等, } \\
2016) \\
+\end{array}$} & $\begin{array}{l}2017 \\
\text { (廖传松等, } \\
2018)\end{array}$ & $\begin{array}{l}\text { 2018-2019 } \\
\text { (本研究) }\end{array}$ & \multicolumn{4}{|c|}{$\begin{array}{l}\text { 生态类型 } \\
\text { Ecological type }\end{array}$} \\
\hline & & & & & & $\mathrm{C}$ & $\mathrm{D}$ & LE & SE \\
\hline 88. 大口黑鲈 Micropterus salmoides & & & & & + & $\mathrm{C}$ & $\mathrm{D}$ & LE & SE \\
\hline $\begin{array}{l}\text { IX 领针鱼目 Beloniformes } \\
\text { (十九)鰔科 Hemiramphidae }\end{array}$ & & & & & & & & & \\
\hline 89. 间下鰔 Hyporhamphus intermedius & & & & & + & $\mathrm{O}$ & $\mathrm{U}$ & LO & SE \\
\hline
\end{tabular}


白敬沛, 黄耿, 蒋长军, 章伟成, 王齐东, 姚伦广 (2020) 丹江口水库鱼类群落特征及其历史变化. 生物多样性, 28, 1202-1212. http://www.biodiversity-science.net/CN/10.17520/biods.2020009

\section{附录 2 伦峰等(2016)、廖传松等(2018)和本研究鱼类组成差异及成因分析}

Appendix 2 Differences of fish composition with cause analysis among Lun et al (2016), Liao et al (2018) and the present study

\section{1 鱼类组成差异}

伦峰等(2016)调查共采集到鱼类62种，隶属5目11科49属，鲤形目鱼类有2科36属44种，占总数的 $71.0 \%$; 鲇形目 2 科 5 属7种，占总数的 $11.3 \%$; 鲇形目 5 科 5 属 7 种，占总数的 $11.3 \%$; 鲑形目 1 科 2 属 3 种，占总数的 $4.8 \%$; 合鳃目 1 科 1 属 1 种, 占总数的 $1.6 \%$ 。鲤科在各科鱼类中种类最多, 共有 40 种(原文中为 32 种), 占总数的 $64.5 \%$ (原文中为 $51.6 \%$ ); 其次是鲿科，共有 5 种，占 $8.1 \%$; 鳅科4种，占 $6.5 \%$; 银鱼科和鮨科各 3 种，分别占 $4.8 \%$; 鲇科 2 种，占 $3.2 \%$; 合鳃鱼科、刺鳅科、虾虎鱼科、鳢科、塘鳢科等均为 1 种，分别占 $1.6 \%$ (附录1)。

廖传松等 $(2018)$ 调查共采集到鱼类 25 种, 隶属 4 目 6 科 21 属, 鲤形目鱼类有 1 科 16 属 18 种, 占总数的 $72.0 \%$; 鲇形目 2 科 2 属 4 种, 占总数的 $16.0 \%$; 鲈形目 2 科 2 属 2 种, 占总数的 $8.0 \%$; 鲑形目 1 科 1 属 1 种, 占总数 的 $4.0 \%$ 。鲤科在各科鱼类中种类最多，共有 18 种，占总数的 $72.0 \%$; 其次是鲿科，共有 3 种，占 $12.0 \%$; 银鱼 科、鲇科、鮨科、鳢科均为 1 种, 分别占 $4.0 \%$ (附录 1 )。

本研究(2018-2019年)调查共采集到鱼类33种，隶属5目11科29属，鲤形目鱼类2科20属22种，占总数的 $66.7 \%$; 鲇形目 3 科 3 属 5 种, 占总数的 $15.2 \%$; 鲇形目 4 科 4 属 4 种, 占总数的 $12.1 \%$; 鲑形目、领针鱼目均为 1 科 1 属 1 种, 占总数的 $3.0 \%$ 。鲤科在各科鱼类中种类最多, 共有 21 种, 占总数的 $63.6 \%$; 其次为鲿科, 共有 3 种, 占 $9.1 \%$; 银鱼科、鳅科、鮰科、鲇科、鮨科、虾虎鱼科、鳢科、太阳鱼科、鱵科均为 1 种, 分别占 $3.0 \%$ (附 录1)。

本研究(2018-2019年)与伦峰等(2016)相比, 调查到的丹江口水库鱼类少 29 种, 其中鲤科鱼类少 19种, 魭科鱼类少 2 种，鳅科鱼类少 3 种，银鱼科和鮨科鱼类各少 2 种，鲇科鱼类少 1 种，刺鳅科鱼类没有采集到。本 研究(2018-2019年)与廖传松等(2018)相比, 调查到的丹江口水库鱼类多8种, 其中鲤科鱼类多3种, 鳅科、鮰 科、虾虎鱼科、太阳鱼科、鮓科各多1种。廖传松等(2018)与伦峰等(2016)相比，调查到的丹江口水库鱼类 少 37 种, 其中鲤科鱼类少 22 种, 鲿科鱼类少 2 种, 银鱼科和鮨科鱼类均少 2 种, 鲇科鱼类少 1 种, 合鳃鱼科、刺 鳅科、虾虎鱼科、塘鳢科末采集到。

\section{2 差异成因分析}

本研究(2018-2019年)采集到鱼类33种，远少于伦峰等(2016)于2013-2014年在河南库区调查到的62种, 但略多于廖传松等(2018)于2016年调查到的25种。造成差异的原因可能有以下几个方面:

(1) 调查强度。可能由于调查强度相对低的原因, 伦峰等(2016) 调查到的不常见鱼类如三角鲂 (Magalobrame tarminalis)、鲩(Ochetobibus elongatus)、尖头鲌(Culter oxycephalus)等在廖传松等(2018)和本 研究(2018-2019年)中均没有采集到。另如，作者前期和本研究(2018-2019年)期间，在丹江口水库均只采集 到1种银鱼科鱼类, 即太湖新银鱼(Neosalanx taihuensis), 这也与丹江口水库的银鱼引种历史及其他研究结 果一致(杨战伟等, 2012; 包洪福, 2013; Yuan et al, 2016; 廖传松等, 2018), 但伦峰等(2016)的研究中还采集 到寡齿短吻银鱼(Neosalanx oligodoitis)和长江银鱼(Hemisalanx brachyrostralis)。

(2)种属划分。伦峰等(2016)中存在一些种属划分的争议, 以及某些鱼由于古今异名被错划分为几种的 情况，例如大鳍刺鰟鮍(Acanthorhodeus macropterus)和大鯺䁤(Acheilognathus macropterus)在该研究中被划 分为两种不同的鱼。

(3)生境变化。伦峰等(2016)的研究主要集中在2013-2014年，而2014年后水库再次加高蓄水位(Pan et al, 2018), 导致库区流水生境进一步丧失, 可能也是导致部分鱼类(特别是喜流水性鱼类如马口鱼Opsariichthys bidens、宽鯺鱲Zacco platypus等)在廖传松等(2018)和本研究(2018-2019年)中没有被采集到的原因之一。

(4)调查区域及采样点设置。(a)调查区域: 伦峰等(2016)仅涉及到河南库区, 廖传松等(2018)和本研究 (2018-2019年)的采样点大致覆盖了整个库区, 代表性相对更强(图A1)。(b)采样点数目：伦峰等(2016)为6个, 廖传松等(2018)为4个, 本研究(2018-2019年)的采样点为5个(图A1及表A1)。(c)采样点位置: 伦峰等(2016) 
白敬沛, 黄耿, 蒋长军, 章伟成, 王齐东, 姚伦广 (2020) 丹江口水库鱼类群落特征及其历史变化. 生物多样性, 28, 1202-1212. http://www.biodiversity-science.net/CN/10.17520/biods.2020009

的采样点也主要集中于库区, 且其采样点S4、S5、S6较为集中, 与本研究(2018-2019年)的马蹬镇采样位点 大致位于同一区域(见图A1蓝色椭圆标出部分); 而本研究(2018-2019年)的采样点与廖传松等(2018)的采样 点较为一致, 但多 1 个马蹬镇采样点。因此, 调查区域及采样点设置可能不是导致本研究与伦峰等(2016)调 查结果差异的主要原因。

(5)调查次数。伦峰等 (2016) 为 5 次, 廖传松等 (2018) 为 1 次, 本研究 (2018-2019年)为 4 次; 本研究 (2018-2019年)与廖传松等(2018)的调查次数相差较大, 而与伦峰等(2016)调查次数相差不大。因此, 调查次 数的不同很可能是导致本研究(2018-2019年)与廖传松等(2018)调查结果存在差异的因素之一, 但可能不是 导致本研究(2018-2019年)与伦峰等(2016)调查结果差异的主要原因。

(6)调查方法。调查方法的差异可能也导致了三者调查结果的不同，伦峰等(2016)主要以撒网为主，辅以 迷魂阵、垂钓、渔民渔获物调查、走访和资料收集等; 廖传松等(2018)主要基于渔民渔获物调查数据; 本研 究(2018-2019年)为多网目复合刺网定量采样和渔民渔获物调查。伦峰等(2016)研究中采用的撒网、迷魂阵 等渔具渔法可能对鱼类(特别是不常见鱼类的)选择性更低、捕捞效率更高，导致调查到的鱼类种类最多; 而 廖传松等(2018)的调查方法相对较为单调，因而导致调查到的种类数较少。

综上所述，本研究(2018-2019年)与伦峰等(2016)调查到的鱼类种类差异成因可能有调查强度、种属划 分、生境变化、调查方法等方面; 而本研究(2018-2019年)与廖传松等(2018)相比，调查次数和采样点数目多 于后者, 调查方法也相对较后者丰富, 可能导致了本研究调查到的鱼类种类数多于后者。

\section{参考文献}

Bao HF (2013) Influence Analysis on Biological Diversity of Danjingkou Reservoir at the Middle Route South-to-North Water Transfer Project. PhD dissertation, Northeast Forestry University, Harbin. (in Chinese with English abstract) [包洪福 (2013) 南水北调中线工程对丹江口库区生物多样性的影响分析. 博士学 位论文，东北林业大学，哈尔滨.]

Liao CS, Xiong MT, Yin Z, Liu JS (2018) Studies on the fishery fishing and community structure of fish in the Danjiangkou Reservoir. Journal of Anhui Agricultural Sciences, 46, 87-90. (in Chinese with English abstract) [廖传松, 熊满堂, 殷战, 刘家寿 (2018) 丹江口水库渔业捕捞及鱼类群落结构研究. 安徽农业科学, 46, 87-90.]

Lun F, Li Z, Zhou BX, Wang CX, Li YY (2016) Investigation of fish resources in Danjiangkou Reservoir in Henan Province. Journal of Henan Agricultural Sciences, 45, 150-155. (in Chinese with English abstract) [ 伦 峰, 李峥, 周本翔, 王晨溪, 李玉英 (2016) 丹江口水库(河南辖区)鱼类资源调查. 河南农业科学, 45, 150-155.]

Yang ZW, Li ZJ, Liu JS, Zhang TL, Ye SW, Zhang H (2012) A comparative study on reproductive characteristics of different spawning stocks of the icefish (Neosalanx taihuensis) in the Danjiangkou Reservoir. Freshwater Fisheries, 42, 58-62. (in Chinese with English abstract) [杨战伟，李钟杰，刘家寿，张堂林，叶少文，张华 (2012) 丹江口水库太湖新银鱼不同繁殖群体的繁殖特征比较. 淡水渔业, 42, 58-62.]

Yuan J, Xia YG, Li ZJ, Yin Z, Liu JS (2016) Changes in fisheries resources in the Hanjiang River and Danjiangkou Reservoir, China. American Fisheries Society Symposium, 84, 179-191. 
白敬沛, 黄耿, 蒋长军, 章伟成, 王齐东, 姚伦广 (2020) 丹江口水库鱼类群落特征及其历史变化. 生物多样性, 28, 1202-1212. http://www.biodiversity-science.net/CN/10.17520/biods.2020009

\section{表A1 不同研究间采样点设置及调查方法比较}

Table A1 Comparison of sampling sites and survey methods among different studies

\begin{tabular}{|c|c|c|c|}
\hline 差异比较 & 伦峰等 (2016) & 廖传松等 (2018) & 本研究 (2018-2019年) \\
\hline 调查区域 & 河南库区 & 湖北库区、河南库区 & 湖北库区、河南库区 \\
\hline 采样点个数 & 6 & 4 & 5 \\
\hline 采样点位置 & $\begin{array}{l}\text { 杨岗(S1)、李沟(S2)、宋岗码头(S3)、狮子 } \\
\text { 岗码头(S4)、双河镇(S5)、王家山码头(S6) }\end{array}$ & 香花镇、凉水河镇、丹江口市、均县镇 & $\begin{array}{l}\text { 马蹬镇、中线渠首、凉水河镇、丹 } \\
\text { 江口市、均县镇 }\end{array}$ \\
\hline 调查次数 & 5 & 1 & 4 \\
\hline 采样方法 & $\begin{array}{l}\text { 以撒网为主、辅以迷魂阵、垂钓; 渔民渔获 } \\
\text { 物调查; 探访水库工作人员、当地居民 }\end{array}$ & 渔民渔获物调查 & $\begin{array}{l}\text { 多网目复合刺网定量采样; 渔民 } \\
\text { 渔获物调查 }\end{array}$ \\
\hline
\end{tabular}
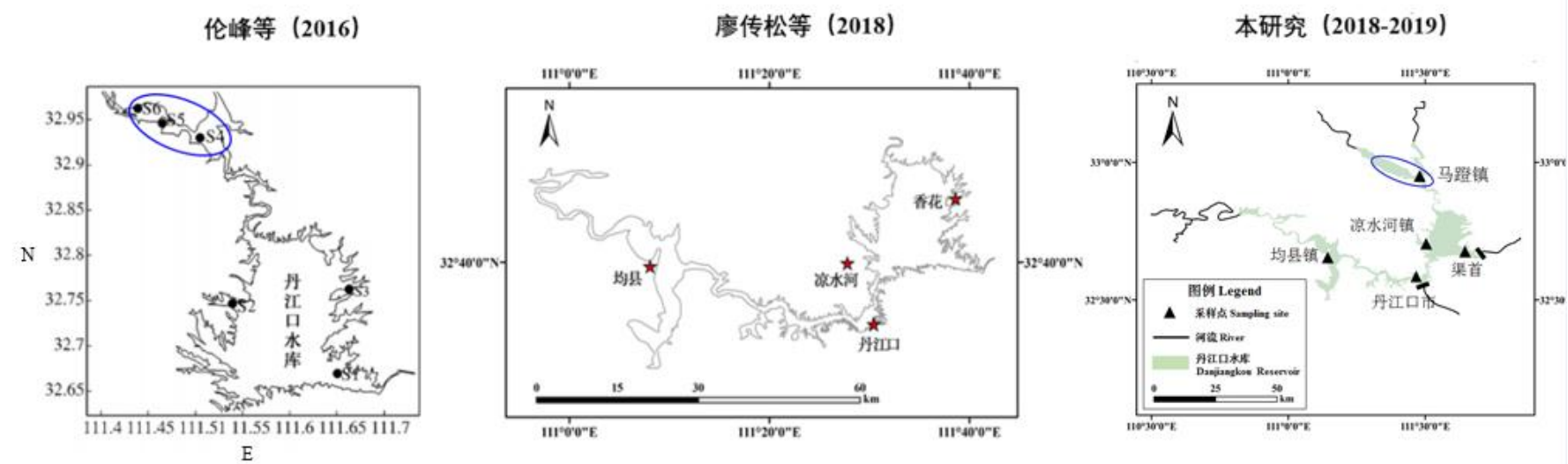

\section{图A1 不同研究间采样点位置比较}

Fig. A1 Differences in sampling sites among different studies 